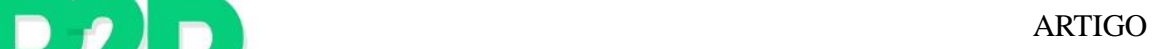

\title{
HOW THE SIGNALS USED BY CAPITALIST SUPPLY CHAINS COULD SERVE A MUTUAL COORDINATION ECONOMY ${ }^{1}$
}

\author{
Bob Haugen \\ ERP and manufacturing supply chain programmer. Working in software for the next economy at \\ http://mikorizal.org. (bob.haugen@gmail.com).
}

\begin{abstract}
Mutual Coordination Economy is a phrase and idea that arose from the P2P Foundation and their Mutual Coordination Economics Working Group. This essay explores the coordination signals used by the most advanced capitalist supply chains, and suggests how those signals could be transformed to become useful for a very different, non-capitalist, social-economic system based on human and ecological needs. It also suggests some even more advanced coordination signals that could be used for that more advanced system. It concludes with some ideas about how to start to implement such a system.
\end{abstract}

Keywords

Mutual Coordination Economy. Capitalist supply chains.

\section{COMO OS SINAIS USADOS NAS CADEIAS DE SUPRIMENTO CAPITALISTAS PODEM SERVIR PARA UMA ECONOMIA DE COORDENACAO MUTUA}

\section{Resumo}

A economia de coordenação mutua é uma ideia que surgiu em um grupo de trabalho do Fundação P2P. Este ensaio explora os sinais de coordenação usados nas cadeias de suprimentos capitalistas, e sugere como esses sinais podem ser transformados para serem úteis para um sistema social e econômico não capitalista muito diferente, ba seado nas necessidades humanas e ecológicas. Também sugere alguns sinais de coordenação ainda mais avançadas que podem ser usados para esse sistema mais avançado. Conclui com algumas ideias sobre como começar a implementar um sistema deste tipo

Palavras-chave

Economia de coordenação mutua. Cadeias de fornecimento capitalistas.

Mutual Coordination Economy is a phrase and idea that arose from the P2P Foundation and their Mutual Coordination Economics Working Group. This essay explores how the coordination signals used in current capitalist supply chains might be transformed for such an economy.

\footnotetext{
${ }^{1}$ Available in: https://blog.p2pfoundation.net/how-the-signals-used-by-capitalist-supply-chains-could-serve-a-mutualcoordination-economy/2016/02/10
} 


\section{INTRODUCTION}

I will look at the coordination signals used by the most advanced capitalist supply chains, and suggest how those signals could be useful for a very different, non-capitalist, socialeconomic system based on human and ecological needs. And suggest some even more advanced coordination signals that could be used for that more advanced system.

I confess that I am out of touch with the most advanced capitalist supply chains. My experience was in the 1990's, when the current understanding and practices of capitalist supply chains were undergoing rapid change and development. They have continued to change and develop, and for understanding the changes since 2000 or so, I am dependent on published articles, some of which are listed in the references at the end.

If you want to know a lot more about supply chains from the viewpoint of globalized commerce, check out Logistical Worlds.

Toward the end of these notes, I will suggest how we can start to implement a mutual coordination economy composed of existing organizations.

Michael Linton comments that Demand Chains are also important: supply chains are only part of the total economic ecosystems that a capitalist company is enmeshed in. So before we consider a mutual coordination economy, we will look at those ecosystems and how they shoot themselves in both feet in capitalism, so we can think about how we can do better.

\section{NECESSARY BUT NOT SUFFICIENT}

Before we get too deep into technology, I want to emphasize that the technology of coordination signals in economic networks is necessary for a mutual coordination economy, but it is not sufficient, nor is it even the main requirement. The main requirement is boots on the ground: live people organizing together in mutually-beneficial production and distribution networks that take care of their daily lives and their ecosystems.

The other insufficiency of coordination signals is that they assume some organized activities to coordinate. Another important aspect of an economy is the development and organization of means of production and distribution and the people who work in them. (That is the part that seems weakest to me in the existing organizations that I know of, which would be 
candidates for a mutual coordination economy. Can't have an economy without producing goods. Please comment if you know more than I do about this problem.)

So in many ways, coordination signals are only part of the story.

\section{EXAMPLES OF CAPITALIST SUPPLY CHAIN SIGNALS}

While the most common demand signal is probably a customer order, and the most precise demand signal is probably a point-of-sale event, I will focus first on something else that is starting to be called "Demand Sensing".

\section{DEMAND SENSING}

With the rush of so-called "big data" - notably the escalation of real-time data - now available for demand forecasting, new toolsets are required to drive advanced inventory planning. Such tools are now available: They synthesize massive amounts of data - much of it real-time - such as multiple customer point-of-sale (POS) data streams, variables related to weather conditions, economic indicators, sales of competing products, social media hype, and a host of additional indicators. The Journal of Business Forecasting notes that demand sensing sorts out the flood of data in a structured way to recognize complex patterns and to separate actionable demand signals from a sea of "noise."

Demand sensing technology has already been adopted by companies that are recognized as having the most progressively managed supply chains. Indeed, investments in demand sensing solutions are growing more rapidly than supply chain spending in general.

According to an IDC Marketscape assessment of sensing and planning vendors published in September 2013, demand sensing initiatives accounted for 8.5 percent of supply chain spending in 2013, and are expected to reach 8.7 percent in 2015. (from http://www.supplychain247.com/article/new_perspectives_on_the_value_of_demand_sensing)

This is partly why Facebook and Google want all your data... 


\section{D Bob Haugen}

\section{POINT-OF-SALE EVENTS}

Often recorded by a bar code reader at a checkout counter in a retail store. Or a shopping cart checkout at an e-commerce store.

The POS event means somebody bought something, and it no longer exists in inventory. If it is a repetitively-purchased item, the seller might want to replace it. The manufacturer might want to make more, and obtain all the required components and other resources so they can make more.

So a POS event may travel upstream along the supply chains until it hits somebody who does not pass it along. Which might be an Information decoupling point in the supply chain. (More on decoupling points later.)

\section{SUPPLY SIGNALS}

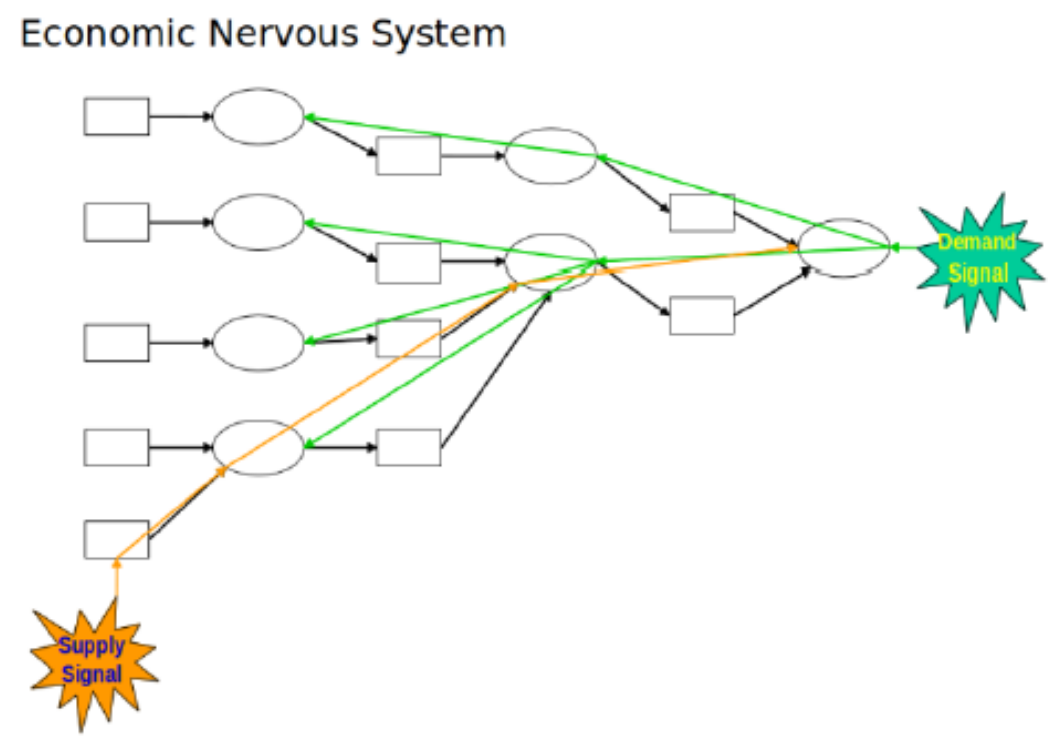

A supply signal could mean that something went wrong with an expected input to an upstream process. These are not used a lot in most commercial supply chains, maybe because it would require the supplier to admit that they had a problem. Supply problems may require reactive replanning. Reactive replanning was implemented by NASA for the space shuttle, and became a commercial product called Red Pepper, which was bought by Peoplesoft, which was 
bought by Oracle. It was brilliant but expensive and difficult to implement. They wrote a book about it. Since then, several other commercial products have emerged. Reactive replanning is also used in game software: according to the wikipedia article, Creatures is an implementation of reactive replanning. But regardless, in material production, it's often best done by humans using good old human judgment, or at least by software that keeps humans in the loop. The signal is useful to them, too.

\section{HOW CAPITALIST SUPPLY CHAIN SIGNALS ARE TRANSMITTED (EDI)}

\section{How capitalist supply chain signals are transmitted (EDI)}

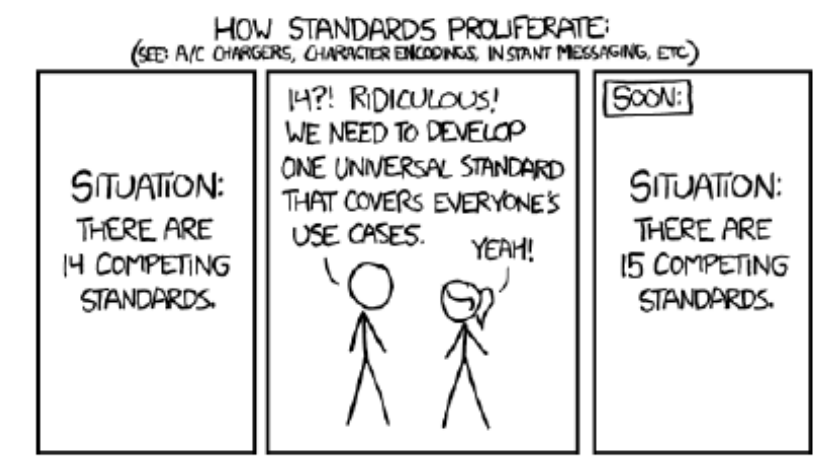

http://xkcd.com/927/

From the Wikipedia article on Electronic Data Interchange [EDI]:

Some major sets of EDI standards:

- The UN-recommended UN/EDIFACT is the only international standard and is predominant outside of North America.

- The US standard ANSI ASC X12 (X12) is predominant in North America.

- GS1 EDI set of standards developed the GS1 predominant in global supply chain

- The TRADACOMS standard developed by the ANA (Article Number Association now known as GS1 UK) is predominant in the UK retail industry.

- The ODETTE standard used within the European automotive industry

- The VDA standard used within the European automotive industry mainly in Germany 
- The HL7 a semantic interoperability standard used for healthcare administrative data.

In the 1990's, as global commerce grew and US companies needed to exchange electronic documents between the US and the rest of the world, some projects began to try to develop, as the cartoon says, "one universal standard that covers everyone's use cases".

For example,

- RosettaNet

- EbXML

$\checkmark \quad$ I worked on ebXML, and joined with some other people at the time to propose that we should just adopt RosettaNet and be done. Needless to say, that proposal was not adopted...I can explain why in gruesome detail, but it all boiled down to capitalist competition.

So those two joined the other competing standards, because companies continued to use all of the others listed above, as well as proprietary standards for large supply chains like Walmart's. As always, XKCD cartoons are non-fiction...

\section{VANS}

To handle the competing "standards" that a single company might need to implement, Value Added Networks emerged to translate between them all. So, while EDI started out P2P, it became increasingly centralized, although in several VAN suppliers rather than a single center. These have evolved into service companies that take over the business integration problems among many companies. GXS claims to be the "Global Leader" in such services. Of course, most likely several competitors claim the same title... 


\section{DEPENDENT DEMANDS}

The demands signaled by customer orders and point of sale events are for end products that might be created from several layers (called "tiers" in supply chains) of components and suppliers (thus the phrase "supply chain").

The signals for end items need to be propagated through all of the dependent components (and production organizations) until they reach something that is on hand and available. That propagation is done through bills of material and work breakdown structures.

Often the bills of material are shared along the supply chain so component makers can anticipate the dependent demands of the end item production schedules. I saw this happen with the late lamented Saturn division of General Motors, when they shared their bills of material with their suppliers, sent them their auto production schedule, and expected the suppliers to figure out and deliver what was required when. Which the suppliers largely did. (This also fits into the next section ...)

The direct propagation of the end product demand (the " dependent demand explosion ") may stop when it reaches a component that is on hand and available. That is known as the Material Decoupling Point. The supply chain is often planned and organized so that this decoupling point happens where the component that is required either has a long lead time, or large capital equirements so that economies of scale apply. Another decoupling point may happen deeper in the supply chain, called the Information Decoupling Point, because even if the demand signal does not require immediate action by a supplier, the information may be useful for planning. See the current P2PF article on Distributed Car Manufacturing and Sustainability.

\section{THE UNEASY TRANSITION FROM SUPPLY CHAINS TO ECOSYSTEMS: THE VALUE-CREATION/VALUE-CAPTURE DILEMMA}

https://www.academia.edu/10252910/The_uneasy_transition_from_supply_chains_to_ecosystem s_The_value-creation_value-capture_dilemma

Or, how capitalist supply chains defeat themselves. 
Capitalist supply chains and economic ecosystems generate surplus value (think: profit!). A competition emerges from the participants in these networks to capture more of the surplus value for themselves. This competition often degrades the performance of the supply chain or ecosystem as a whole.

When I was working on commercial supply chains in the 1990's, we used to say, "the best supply chain wins, not the best individual company". The other thing we found was that the individual companies often get in the way of the best supply chain performance.

The supply chain signals are actually P2P coordination messages between the people in one node in the supply chain and the people in the neighboring nodes. Often between people who are responsible for material requirements management for a production department, sometimes between line workers who make and use components.

For example, in a Bosch auto parts plant where I worked, the people on the fuel injector line had close relationships with the people at the auto assembly plants who put the injectors into engines. And other lines in the auto parts plant had close relationships with the people who used their parts. Those would often be closer working relationships than with the people in the same plant who worked on different production lines.

Inside the plant, people worked off kanbans, which were probably the original supply chain $\mathrm{P} 2 \mathrm{P}$ coordination signal. Sometimes kanbans were used between one plant and another, in the form of labeled tote pans which were sent empty from the consuming plant to the producing plant who would fill them up and return them.

A prime example of supply chain self-damage: Dell computers, which used to be touted as having a great supply chain, kept pushing their inventory problems upstream to their tier one suppliers. The result was that Dell lost adaptability, because their tier one suppliers (the first leg in their supply chain) were not adaptable, because they had burdened themselves with Dell's inventory problems.

This is a quote from a 2000 paper that lavishes praise on the success of Dell's business model at that time:

Dell's production system applies principles of lean manufacturing and just-in-time (JIT) production that were first employed by Japanese manufacturers such as Toyota, and have been applied extensively in the U.S. PC industry. These principles aim to minimize parts inventories by requiring suppliers to restock parts only as they are needed, and often to maintain ownership of 
parts until they are used. In effect, the PC company is pushing the upstream inventory problem onto the suppliers, a practice that is viable at least for larger vendors who have the clout to make such demands.

http://www.pcic.merage.uci.edu/papers/2000/dell-feb00.pdf

Soumaya Ben Letaifa writes, in the paper that gave this section its title,

Value co-creation is no longer restricted to a dyad as it involves interaction between at least two socioeconomic networks to which the supplier and the customer belong (Cova and Salle, 2008; Mele and Polese, 2011). This evolution shifts value creation from a linear economic process taking place in a specific production chain to a more networked, open, and emergent process nvolving multiple actors, including customers and competitors (Normann and Ramirez, 1993). This network perspective challenges the underlying assumptions of industrial economics (IO) (cost and demand are known to all firms, technology and innovation are exogenous to firms, and so on) (Pitelis, 2009). In the old goods-dominant logic (Vargo and Lusch, 2008), value, value creation, and value capture are asymmetrically defined by suppliers with an IO focus. Whereas value creation is often synonymous with exchange value or the price the customer is willing to pay (Peteraf and Barney, 2003; Porter, 1985), value capture is measured by the firm's revenues resulting from the value that it created and the price accepted by customers (Pitelis, 2009). Even in recent network- and industry-level studies, the focus remained on the firm or supplier level of analysis and a transactional-cost framework was used to assess how firms capture value (see Adner and Kapoor, 2010; Chatain and Zemsky, 2011). Yet, new forms of networks, called ecosystems, are neither firm-nor market-centric and require a novel multilevel analysis of value creation and capture. Ecosystems are defined as the third pillar of organizational theory, and they need to be addressed differently from markets and hierarchies (Moore, 2006). Many authors are suggesting new ecosystemic methodologies and metrics to evaluate ecosystemic health (performance) (Kanter, 2012; Wieland et al., 2012). The new metrics make it possible to go beyond traditional economic firm-centricity and short-term vision to grasp social and community-based value.

$[\ldots]$

The results clearly show that the shift from supply-chain logic (firm value creation) to ecosystem logic (ecosystemic value co-creation) can be difficult and challenging. More specifically, direct 
competitors rarely behave as partners or complementors, especially when there is no ecosystem leader and coordinator to leverage ecosystemic capabilities.

Indeed, the case study highlights three capabilities that would allow for ecosystemic value cocreation:

1. embracing an ecosystemic mindset;

2. adopting ecosystem management; and

3. building a sustainable social community.

In the present case study, ecosystem creation was based on building collaborative high-tech labs but without leveraging a social strategy to promote value co-creation. The uneasy transition from supply chain to ecosystem failed to deliver the expected ecosystemic value.

But that's only looking at the companies that participate in a business ecosystem. What about the workers? The fabled just-in-time inventory systems and increasingly precarious and haphazard work schedules required for optimum company profits raise hell with individual and especially family lives. See stories about Amazon warehouse workers, for example.

(I understand that the Toyota Production System, the originator of P2P coordination signals in manufacturing supply chains (as far a I know), was not so hard on their workers. If production went down for awhile, the workers would not be sent home or laid off, they would work on process improvement projects. Which is genius...

but only genius in a wage-labor environment. A mutual coordination economy should be able to get beyond wage labor. Simplest way is guaranteed income for all.)

This is not to mention the total ecosystem, the air, water, soil, flora and fauna around the business ecosystem. Do we all live here, and do they all live here, or is the money the only thing that matters?

\section{SIGNALS FOR A MUTUAL COORDINATION ECONOMY}

Let us propose that demand signals for a Mutual Coordination Economy will be driven by human and ecological needs, based on use-value, and not on needs for profit, based on exchange-value. How will those signals become known? Certainly point-of-use signals can be captured somewhat as they are now. They will signal that somebody has used something, and if it is a repetitivelyused item, should be replaced. Summarizing use events over time is a good basis for longer-term 
planning (for example, the farmer plans what to plant next year based on what people ate this year).

But think about the counterparts of demand sensing in terms of sensing human and ecological needs.

\section{NEED-SENSING}

Population density alone signals a constellation of human needs and possibly ecological dangers. New births, deaths, movements of people, all become signals of incipient human needs and ecological effects.

Facebook, Google and Amazon now mine people's searches and statements online for signals of demand, aiming to sell you something. But those same kinds of signals could be used to forecast human needs more toward a sense of the common good.

And any kind of democratic planning process will come up with needs that can become signals. (I disagree with the frequent criticisms of the Parecon democratic planning proposals as unworkable. They are only unworkable if you expect a democratic process to plan everything in great detail, and be the only such input to be considered. But such a process could be a valuable source of signals of need. And it does not need to happen in big meetings. That's what we got social networks for.)

Ecological needs could come from human representatives of bioregional beings in a bioregional planning system, or in a more advanced bioregional system, they could come from Emergy Accounting.

In other words, a Mutual Coordination Economy can work from a much richer set of need signals and need-sensing than a capitalist economy can handle, because capitalist demand signals must have money attached. And Mutual Coordination Economy signals should not need them.

Each of those signals will have to be linked to its dependent needs (what it takes to satisfy the need that was signaled), which then will become signals of need for whatever process can satisfy the dependent need. If no such process exists, then that will become a signal to organize such a process. Those dependent needs might be decided by bills of material or work breakdown structures, just like the capitalist supply chains, but they may require a lot more social analysis. 
For example in Nova Scotia, do we want to privilege trawlers (seriously, they are privileged now) who destroy fish spawning beds over smaller fishing boats who do not destroy fish spawning beds but also don't bring in as many fish? Or is it better to bring in fewer fish so the fish populations can sustain themselves? (See alsonext section.)

I have my own extremely strong opinions, but possibly unfortunately, I think those need to be democratic decisions. (I hope not in the current bought-and-paid-for democracy, though. Although we are getting rid of money in this thought experiment, so that should help.)

Re social analysis, we need to figure out some of the implications of our policy decisions (the dependent demands). So, for example, if we want more small fishing boats, how do we get them? Most of the small fishing boat builders have gone out of business. What will be required to create new fishing boats? And new fishing boat builders? And where are the all the sustainable fishing boat crew members we will need? They have retired and their children want to be something else. What will be required to recruit and train new fishing boat crew members?

\section{BIOREGIONAL ANALYSIS}

The story about Nova Scotia fisheries in the preceding paragraphs is real. It comes from this plan, which resulted in this organization.

The plan and the organization are examples of thinking in bioregions, and understanding that the human economy is part of the bioregional ecology.

Here's another example of a group that is working on what they call Socio-Ecological Enterprises.

Many existing organizations are conducting bioregional analyses, usually focusing on the natural ecosystem, often disregarding the human economy. For example,Conservation Biology Institute (CBI), a non-governmental organization. CBI's tools are open source, too. Many of these organizations, like CBI, are happy to collaborate.

I think most ecological needs are best analyzed bioregionally, not globally, although climate change is one obvious exception. A Mutual Coordination Economy needs to take ecological needs very seriously, or its idea of mutuality is way too limited.

The disconnect between the business economy and the natural ecosystems is a feature of capitalism. Profit usually requires disregarding "externalities" as much as they can get away with, 
and analysis of the natural ecosystem is relegated to academia and nonprofit organizations that stay in their assigned and harmless places.

The P2P Foundation (and others) propose a Bioregional State, which seems to be the correct idea.

\section{INTENT-CASTING}

An Intent is something you want to provide (an offer), receive (a request), or do collaboratively (a proposal). Intent-casting is a term that was popularized by Doc Searls of the Vendor Relationship Management (VRM) community. He describes it as "casting your interests to the world".

The idea is emerging within capitalist relationships, but is also being taken up by communities that are trying to transition out of capitalist relationships: for example, Mutual Aid Networks. And VRM is itself a symptom of changing relationships within capitalist supply chains.

Intent-casting could only happen on something like the World Wide Web, and is enabled by the Web and social networks.

We are working on vocabularies and protocols for intent casting in the Value Flows project which is the focus of the last section.

Intents might find mates: an offer might find a request, and proposal might find collaborators. If so, the participants may start a conversation for action, which was a protocol that emerged from the Cybersyn project. This could be one of the ways to self-organize the various projects we think should be inter-networked to start to evolve a mutual collaboration economic system.

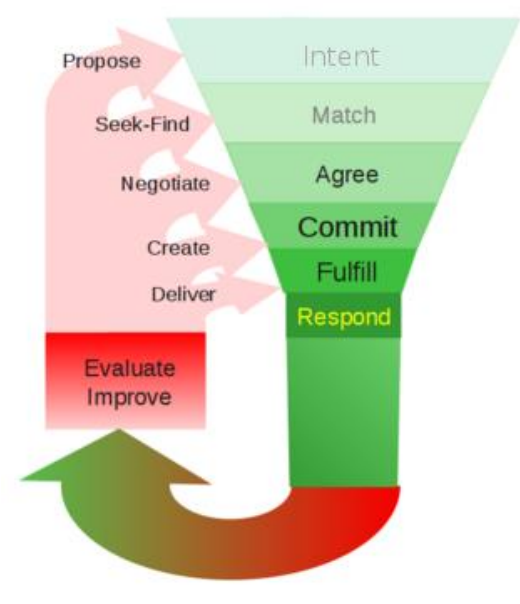




\section{MONEY-GO-ROUNDS}

"Money-go-round" is Michael Linton's catchy phrase, and a lot of this section was inspired by and quoted from this essay of his.

I'd personally like to get rid of money altogether, but here we are in this transitional stage where we need to handle it better for all concerned. Money-go-rounds (circulating money and other resources within a community over and over) makes a community more sustainable. Even after we get rid of money.

\section{The Ten Commandments of Peer Production and Commons Economics says,}

"What is light is global, and what is heavy is local": this is the new principle animating commons-based peer production in which knowledge is globally shared, but production can take place on demand and based on real needs, through a network of distributed coworking and microfactories. Certain studies have shown that up to two-thirds of matter and energy goes not to production, but to transport, which is clearly unsustainable. A return to relocalized production is a sine qua non for the transition towards sustainable production.

So according to that principle, local (or bioregional) resource circulation will be increasingly important in a mutual coordination economy.

Michael Linton says,

Let's say the community has at least 50,000 people, and the per capita per year is over $\$ 20 k-$ so people here spend at least $\$ 1 b$ a year. Just round figures.

To keep the flow of stuff coming in-food, energy, products, services, entertainments, etc etc - we need to spend money out.

Think of the import cost \% in gas, groceries, hard goods, financial services (sometimes VISA is $3 \%$ or $4 \%$ in itself), think of on-line sales, think of vacations, think of taxes. Sorry if that hurt.

It's easy to see how $\$ 700 \mathrm{~m}$ of the $\$ 1 B$ is out of town on the first bounce. In $\$ 1 \mathrm{~b}$ annual spending by local people, maybe $\$ 300$ million returns to people through local wages, salaries, rents. The rest got sucked away, off to do other business, somewhere.

So, just to keep up with ourselves we have to have income from somewhere. Literally, we have to sell out, in some way or another, to the tune of $\$ 700$ m a year. 
For every dollar of local exchange, it seems we need two dollars of in and outflow, of import and export.

That's how that money generates and perpetuates real unsustainability.

[...]

For sustainability, we need demand cycles, chains of connection that go round and stay around.

That's what the money-go-round does.

Here's the same idea explained by Ken Meter and Megan Phillips Goldenberg in their Critical Analysis of Economic Impact Methodologies. In Exploring Economic and Health Impacts of Local Food Procurement.

Impact calculations are often posed as an economic "multiplier." The multiplier is a measure of how many times a dollar earned in a given geographic area cycles through that locale before it leaves.

$[\ldots]$

At minimum, a multiplier must be 1.0. This would mean that each dollar of new revenue leaves the community immediately. Tribal reservations often have multipliers close to one since residents typically have so few choices for buying locally produced goods and services. If the multiplier were 2.0, this would mean that for each dollar of new revenue one additional dollar is spent at another local business - a total of two dollars.

$[\ldots]$

A region of small farms and businesses that buy many of their essential goods and services from each other, and are closely connected socially, might enjoy multipliers as high as 2.6. Some rural advocates claim that a dollar earned by a farm cycles as many as 7 times through the overall economy. This may have once been true (definitive studies of this are lacking), but if this were true, it has not been since 1950, when increased use of mechanization and purchased inputs created dependence on external suppliers, reducing local multipliers.

In a very real way, a multiplier is a measure of the local economic context and its level of connectivity, more than a measure of the change in income itself. The more local firms and residents are interconnected, and trading goods and services with each other, the longer a dollar is likely to cycle through the region, and the higher the multiplier.

And all of these go-rounds would best be based in abioregion. 


\section{D Dob Haugen}

\section{HOW WE CAN IMPLEMENT A MUTUAL COORDINATION ECONOMY BASED ON EXISTING ORGANIZATIONS}

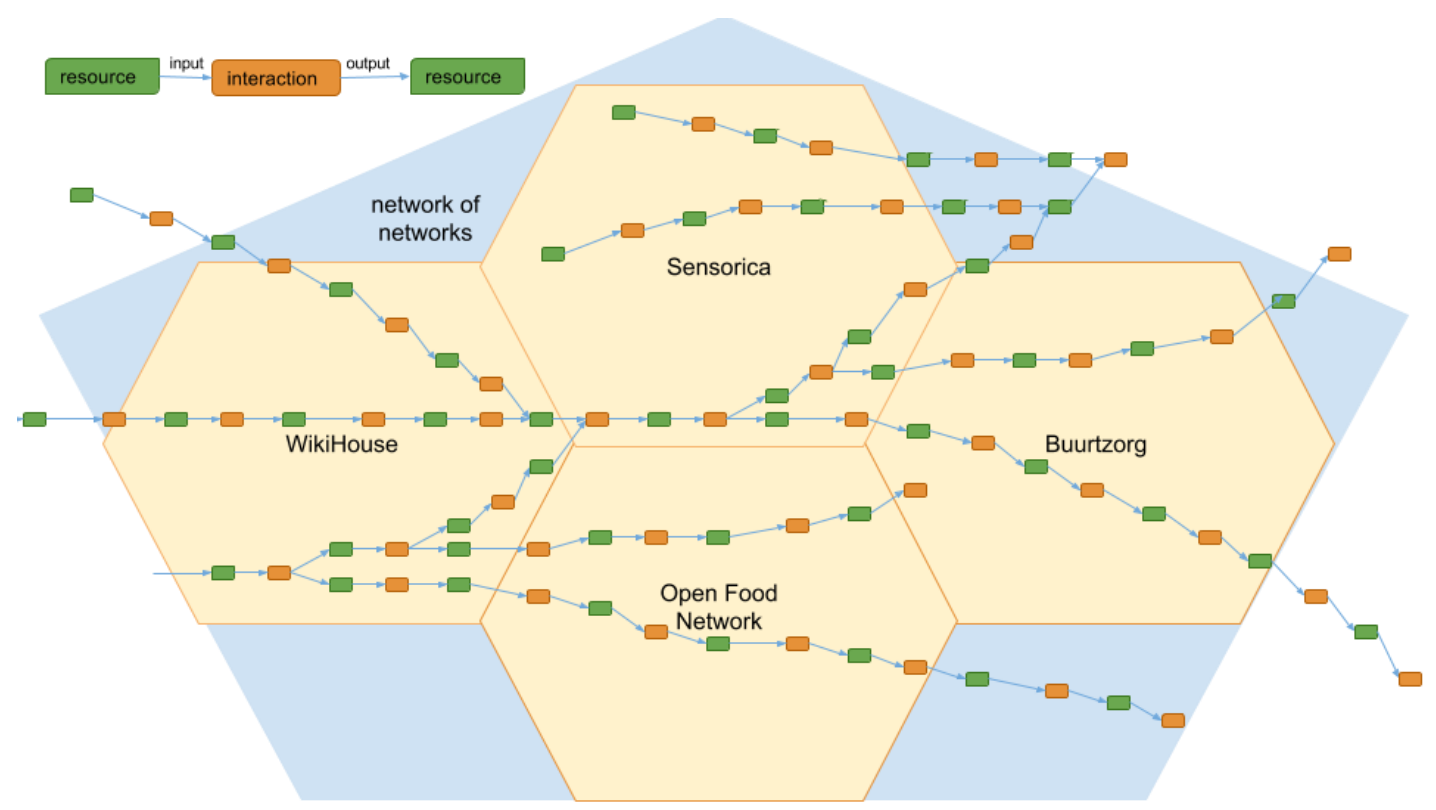

\section{THE VALUE FLOWS PROJECT}

The diagram above comes from the Value Flows project. Its intro says:

Value Flows is a set of common vocabularies to describe flows of economic resources of all kinds within distributed economic ecosystems.

Purpose: to enable internetworking among many different software projects for resource planning and accounting within fractal networks of people and groups.

Or, if that is too many buzzwords, "let's help a lot of alternative economic software projects that are solving different pieces of the same puzzle be able to work together".

In terms of the XKCD cartoon above, yes, that means if it succeeds, there will now be 16 standards. The differences will be that:

- The value flows standard is being designed from a P2P perspective,

- promotes non-capitalist values,

- and can interconnect a Mutual Coordination Economy. 
- Moreover, its vocabulary will be native to the World Wide Web, which is not true of any of the competing EDI standards.

The Value Flows project is one example of a step that can be taken now (is being taken now) to create a Mutual Coordination Economy from a network of existing P2P economic projects. It could be succeeded by some other project with similar goals: projects come and go. But the difficult work is getting the various P2P economic projects to adopt it, or something like it, and to actually coordinate themselves into a global $\mathrm{P} 2 \mathrm{P}$ economy.

We have proofs of concept of the model and logic that the Value Flows project is working on, such as the Sensorica Network Resource Planning and Value Accounting System. That system works as a proof of concept, but it is the wrong architecture for a P2P economic system (it's a monolithic platform, while a P2P economic system needs a protocol, not a platform). Sensoricans are experimenting with Ethereum for a different architecture to run on a blockchain. I am skeptical about blockchains, for all the reasons you can read about in Daniel Harris's article Reasons why I dislike some aspects of The Blockchain - tell me I'm wrong please. Ethereum, like the Bitcoin blockchain, is a platform. Everything needs to buy into and run on Ethereum to interoperate. We are experimenting with a different architecture called Patchwork, built on a protocol rather than a platform, which you can read about in this documentation. But if that turns out to be too limited, we will run on the open Web: the Value Flows vocabulary is defined using Semantic Web techniques. It does not need anything beyond the Web to run. IndieWeb techniques can take it from there.

\section{HOW TO START}

Assuming anybody wants to start now: it's time to experiment. An alert reader will understand that the list below is a thought experiment. I don't know how much of it will work. But I am working on it.

- Identify likely candidates: boots-on-the-ground production and/or distribution organizations who are dedicated to economic transformation. TransforMap could help.

- Request that each of them nominate ambassadors to engage with the other candidate organizations. Get acquainted, cross-fertilize. 
- Find likely existing experiments in technical infrastructure that could accommodate coordination signals: for example, Ethereum (I know I dissed it above, but I could always be wrong, and I know people who are experimenting with it in compatible ways) and Patchwork, which I will be experimenting with. And Indie Web and Semantic Web techniques. And Mutual Credit FairCoop's FairCoin and FairMarket experiments fit in here, too. And so does Matthew Slater's Credit Commons proposal.

- Ethereum, FairCoin, and other singleton blockchains are like VANs: they claim to be decentralized, but you and your partners are all dependent on their blockchain infrastructure.

- I'm also looking at D-CENT, another blockchain framework that seems more comprehensive, and comes with recommendations from people I trust. But I don't know much about it myself yet.

- Patchwork is more like a federation, but will still somewhat limit your connectingsoftware choices.

- Ceptr is another possibility, but it (like Patchwork) is immature.

- Request that the ambassadors connect with all of the cooperating candidate infrastructures.

- They could start with Intents, and circulate them along all of the candidate infrastructures, and match intents among the on-the-ground organizations. And evolve from there into actual resource transfers.

- Use the Value Flows vocabulary to communicate between whatever systems each organization is using internally. The Value Flows gang can help.

- Collaborate with, and incorporate the work of, existing bioregional ecosystem organizations.

- May the best infrastructure(s) win! But the point is not the infrastructure, the point is to internetwork the organizations.

The idea here is to keep the resources going around and around in the interconnected communities, triggered by signals of need or intent, to make the mutual coordination economy come to life. 


\section{WHERE TO GO NEXT}

Michel Bauwens says,

What is missing is the interaction between the stigmergic interaction of production communities and their entrepreneurial coalitions, with the level of democratic planning ..

Here's how I see it:

Democratic councils set limits and priorities as well as conditions for investments.

The ethical market sector and productive communities can get this funding for projects that are aligned.

They mutually coordinate activities through open supply chains and accounting and have deliberation mechanisms to increase mutual coordination.

A meta-level intervenes in case of structural imbalances that cannot be solved by these grassroots coordination levels, which is also feedback for the next iterations of democratic planning.

More at Commons Transition.

\section{REFERENCES}

BAUWENS, Michel. Mutual coordination of physical production through peer production. 2014. Disponível em:

<http://p2pfoundation.net/Mutual_Coordination_of_Physical_Production_through_Peer_Producti on>. Acesso em: 16 abr. 2016.

BAWEJA, Vijay. Get point of sale data: It's not only about Demand. Disponível em: <https://supplychainminded.com/point-sale-data-its-demand/>. Acesso em: 16 abr. 2016.

BULLWHIP EFFECT. In: WIKIPÉDIA, a enciclopédia livre. Flórida: Wikimedia Foundation, 2014. Disponível em: <

https://en.wikipedia.org/w/index.php?title=Bullwhip_effect\&oldid=707015433>. Acesso em: 16 abr. 2016.

EDI BASIC. What is EDI (Electronic Data Interchange)? Disponível em: <http://www.edibasics.com/what-is-edi/>. Acesso em: 16 abr. 2016. 
ELECTRONIC DATA INTERCHANGE. In: WIKIPÉDIA, a enciclopédia livre. Flórida: Wikimedia Foundation, 2014. Disponível em:

$\langle$ https://en.wikipedia.org/w/index.php?title=Electronic_data_interchange\&oldid=714698853 $>$. Acesso em: 16 abr. 2016.

EUROPEAN COMMISSION. Reducing emissions from transport. 2016. Disponível em: <http://ec.europa.eu/clima/policies/transport/index_en.htm>. Acesso em: 16 abr. 2016.

GS1 US. Point of sale data sharing workgroup. Disponível em:

<https://www.gs1us.org/industries/apparel-general-merchandise/workgroups/point-of-sale-datasharing>. Acesso em: 16 abr. 2016.

GXS. Fifth \& Pacific, Inc.: turns to gxs to digitize its supply chain. Disponível em: <http://www.gxs.com/assets/uploads/pdfs/caseStudies/CS_Fifth_Pacific_GXS.pdf?3a7653\&_ga= 1.22766457.334164471.1453285913>. Acesso em: 16 abr. 2016.

HAUGEN, Bob. How the demand signals used by current supply chains can serve broader mutual coordination. 2016. Disponível em:

$<$ http://p2pfoundation.net/How_the_Demand_Signals_Used_by_Current_Supply_Chains_Can_S erve_Broader_Mutual_Coordination>.Acesso em: 16 abr. 2016.

HEYLIGHEN, Francis. Self - organization of complex, intelligent system: an action ontology for transdisciplinary integration. Disponível em: <http://pespmc1.vub.ac.be/papers/ECCOparadigm.pdf>. Acesso em: 16 abr. 2016.

INSTITUTE OF MANAGEMENT ACCOUNTANTS. Tools and techniques for implementing integrated supply chain management. Business Performance Management, Montvale, v. 6, n. 7, p.1-35. 1999. Disponível em: <http://www.imanet.org/docs/default-

source/thought_leadership/operations-process-management-

innovation/tools_and_techniques_for_implementing_integrated_supply_chain_management.pdf? sfvrsn=2>. Acesso em: 16 abr. 2016.

I-TINERARY TRAVEL SOLUTIONS. Don't get stuck at the airport: get notiflyer(tm). 2001. Disponível em: <http://www.prnewswire.com/news-releases/dont-get-stuck-at-the-airport---getnotiflyertm-82468087.html>. Acesso em: 16 abr. 2016.

KANBAN. In: WIKIPÉDIA, a enciclopédia livre. Flórida: Wikimedia Foundation, 2016. Disponível em: 〈https://pt.wikipedia.org/w/index.php?title=Kanban\&oldid=45222160>. Acesso em: 16 abr. 2016.

MARTIN, C; TOWILL, Denis R.. Supply chain migration from lean and functional to agile and customised. Supply Chain Management: an international journal, [s.1.], v. 5, n. 4, p.206-213, out. 2000. Emerald. http://dx.doi.org/10.1108/13598540010347334.

MISHRA, Devendra. The last 100 feet of the supply chain: can RFID navigate through the "black hole"?. Graziadio School of Business and Management, Los Angeles, v. 11, n. 3. 2008. 
Disponível em: <https://gbr.pepperdine.edu/2010/08/the-last-100-feet-of-the-supply-chain/>. Acesso em: 16 abr. 2016.

NIEUWENHUIS, Paul; KATSIFOU, Eleni. More sustainable automotive production through understanding decoupling points in leagile manufacturing. Journal of Cleaner Production, Wales, v. 95, p.232-241, 15 maio 2015. Disponível em:

<http://www.sciencedirect.com/science/article/pii/S0959652615002103>. Acesso em: 16 abr. 2016.

OLHAGER, Jan. The role of decoupling points in value chain management. Contributions to Management Science, [s.1.], p.37-47, 8 set. 2011. Springer Science + Business Media. http://dx.doi.org/10.1007/978-3-7908-2747-7_2.

ORACLE. Supply chain best practice: demand planning using point-of-sale data. 2006. Disponível em: <http://www.oracle.com/us/products/applications/ebusiness/scm/062128.pdf>. Acesso em: 16 jun. 2016.

P2P FOUNDATION. Distributed car manufacturing and sustainability. 2016. Disponível em: $<$ http://p2pfoundation.net/Distributed_Car_Manufacturing_and_Sustainability>.Acesso em: 16 abr. 2016.

P2P FOUNDATION. Economic calculation problem. 2016. Disponível em:

<http://p2pfoundation.net/Economic_Calculation_Problem>. Acesso em: 16 abr. 2016.

P2P FOUNDATION. Stigmergy. 2012. Disponível em: 〈http://p2pfoundation.net/Stigmergy>. Acesso em: 16 abr. 2016.

PRIMAVERA, Daniele; SHI, Hang. Unlocking the power of POS. 2014. Disponível em: <http://www.scmr.com/article/unlocking_the_power_of_pos>. Acesso em: 16 abr. 2016.

SOCIETY, Flok. Research methdolology. 2014. Disponível em:

<http://en.wiki.floksociety.org/w/Research_Methdolology>. Acesso em: 16 abr. 2016.

WIKNER, Joakim; JOHANSSON, Eva. Inventory classification based on decoupling points. Production \& Manufacturing Research, [s.1.], v. 3, n. 1, p.218-235, jan. 2015. Informa UK Limited. http://dx.doi.org/10.1080/21693277.2015.1067845.

\section{LINKS}

http://p2pfoundation.net/How_the_Demand_Signals_Used_by_Current_Supply_Chains_Can_Ser ve_Broader_Mutual_Coordination

https://en.wikipedia.org/wiki/Kanban 
http://p2pfoundation.net/Economic_Calculation_Problem

http://p2pfoundation.net/Mutual_Coordination_of_Physical_Production_through_Peer_Productio $\mathrm{n}$

http://p2pfoundation.net/Stigmergy

http://p2pfoundation.net/Distributed_Car_Manufacturing_and_Sustainability

http://www.sciencedirect.com/science/article/pii/S0959652615002103

http://en.wiki.floksociety.org/w/Research_Methdolology

http://ec.europa.eu/clima/policies/transport/index_en.htm

http://www.springer.com/cda/content/document/cda_downloaddocument/9783790827460-

c1.pdf?SGWID=0-0-45-1269241-p174127782

http://www.tandfonline.com/doi/full/10.1080/21693277.2015.1067845

http://www.slideshare.net/nixianshi/supply-chain-migration-from-lean-and-functional-to-agileand-customised

https://books.google.com/books?id=ya8YYSN406kC\&pg=SA6-PA14\&lpg=SA6-

PA14\&dq=airline+\%22trip+repair\%22\&source=bl\&ots=zwLDvnu8nB\&sig=elCmqab36KcTE5IwvTPzHMxIyc\&hl=en\&sa=X\&ved=0ahUKEwjr7bfCl6rKAhXJqR4KHYVuCj 8Q6AEIJjAC\#v=onepage\&q=airline\%20\%22trip\%20repair\%22\&f=false

http://www.prnewswire.com/news-releases/dont-get-stuck-at-the-airport — get-notiflyertm82468087.html

http://www.pmizgala.com/docs/Magellan.pdf

http://supplychainminded.com/point-sale-data-its-demand/

http://www.scmr.com/article/unlocking_the_power_of_pos

https://en.wikipedia.org/wiki/Bullwhip_effect

http://www.pcic.merage.uci.edu/papers/2000/dell-feb00.pdf

https://drive.google.com/file/d/0Bz8cVS8LoO7Odzg1dVdmdXZmVzg/view

https://books.google.com/books?id=7ffUAAAAQBAJ\&pg=PT55\&lpg=PT55\&dq=pushing+inve ntory+problem+upstream\&source=bl\&ots=JaDWDrUECT\&sig=1DzNEEx3j6Zrxwa1gAcibRpE 4Qo\&hl=en\&sa=X\&ved=0ahUKEwiC1P- 
DpqrKAhXJth4KHRq6BF0Q6AEIKjAC\#v=onepage\&q=pushing\%20inventory\%20problem\%20 upstream\&f=false

https://books.google.com/books?id=MVAi8MpPUOAC\&pg=PA254\&lpg=PA254\&dq=pushing+i nventory+problem+upstream\&source $=$ bl\&ots $=9 q 2 X 7$ WiGKA\&sig=I1cjezRftyAvS9g8A9pwLW hIhb8\&hl=en\&sa=X\&ved=0ahUKEwiC1P-

DpqrKAhXJth4KHRq6BF0Q6AEIITAA\#v=onepage \&q=pushing\%20inventory\%20problem\%20 upstream\&f=false

https://github.com/valueflows/valueflows/issues/82

https://en.wikipedia.org/wiki/Electronic_data_interchange

http://www.edibasics.com/what-is-edi/

http://www.gxs.com/

http://www.gxs.com/assets/uploads/pdfs/caseStudies/CS_Fifth_Pacific_GXS.pdf?3a7653\&_ga=1 .22766457 .334164471 .1453285913

https://www.google.com/webhp?sourceid=chrome-instant\&ion=1\&espv=2\&ie=UTF-

$8 \# q=$ supply+chain+demand+planning + point + of + sale \&start $=10$

https://books.google.com/books?id=eue8KAZ4mn4C\&pg=PA76\&lpg=PA76\&dq=supply+chain+ point+of + sale+events \&source=bl\&ots $=7 \mathrm{Ld} 3 \mathrm{gwLW} 0 \mathrm{~F} \&$ sig $=$ bqEmxrgun Y81n55W1pikFZy5ZwA $\& h l=e n \& s a=X \& v e d=0 a h U K E w i Q v P 6 s p K r K A h W L O D 4 K H f 6 E B q 04 C h D o A Q g b M A A \# v=o n e p a$ ge \&q=supply $\% 20$ chain $\% 20$ point $\% 20$ of $\% 20$ sale $\% 20$ events $\& \mathrm{f}=$ false

http://www.retailsolutions.com/company/news-events/press-releases/walgreens-goes-live-datasharing-program-suppliers-using-demand\#.VpgYKHUrJNA

http://www.oracle.com/us/products/applications/ebusiness/scm/062128.pdf

https://www.gs1us.org/industries/apparel-general-merchandise/workgroups/point-of-sale-datasharing

https://ieondemand.com/divisions/supply-chain/events/9/presentations/is-your-supply-chainready-to-serve-at-the-point-of-sale

https://gbr.pepperdine.edu/2010/08/the-last-100-feet-of-the-supply-chain/

http://www.imanet.org/docs/default-source/thought_leadership/operations-process-managementinnovation/tools_and_techniques_for_implementing_integrated_supply_chain_management.pdf? sfvrsn=2

http://www.bearingpoint.com/en-us/adaptive-thinking/digital/supply-chain-navigator/ 
http://www.opsrules.com/supply-chain-optimization-blog/bid/313709/How-to-Use-POS-Data-toImprove-Supply-Chain-Performance

http://www.supplychainshaman.com/supply-chain-2/supply-chain-excellence/seven-sins-ofdemand-planning/

http://demandplanning.net/POS.htm

http://www.europeanbusinessreview.com/?p=605

http://blog.toolsgroup.com/en/sensing-demand-at-point-of-sale-part-2-demand-signal-repositories http://www.supplychain247.com/article/new_perspectives_on_the_value_of_demand_sensing http://www.supplychain247.com/article/5_lessons_for_supply_chains_from_the_financial_crisis/ one_network_enterprises

http://www.jda.com/realresultsmagazine/view-article.cfm?did=705

http://supplychainminded.com/point-sale-data-its-demand/

http://www.scmr.com/article/unlocking_the_power_of_pos

http://andrewg-crabtreeanalytics.blogspot.com/2012/06/point-of-sale-data-supply-chain.html

http://www.gxs.com/assets/uploads/pdfs/caseStudies/CS_Daniels_GXS.pdf?3a7653\&_ga=1.3582 6658.334164471 .1453285913

https://docs.google.com/document/d/1q6hEpH75Q0VkkCIFUAJhXejrBZqD_j6gFhkmKNROMQ/edit

https://www.academia.edu/10252910/The_uneasy_transition_from_supply_chains_to_ecosystem s_The_value-creation_value-capture_dilemma 